\title{
Aspirin for Preventing Hemodialysis-associated Chronic Hepatitis C Infections
}

\section{Hemodiyaliz Ilișkili Kronik Hepatit C Enfeksiyonlarına Karșı Korunmada Aspirin}

\author{
๑ Tayibe BAL1, • Yusuf ÖNLEN2, ๑ Selma llkay ŞAHIN33, ๑ Faruk Hilmi TURGUT4 \\ 1 Siirt State Hospital, Clinic of Infectious Diseases and Clinical Microbiology, Siirt, Turkey \\ 2 Mustafa Kemal University Tayfur Ata Sökmen Faculty of Medicine, Department of Infectious Diseases and Clinical Microbiology, Hatay, Turkey \\ ${ }^{3}$ Nusaybin State Hospital, Clinic of Infectious Diseases and Clinical Microbiology, Mardin, Turkey \\ 4Mustafa Kemal University Tayfur Ata Sökmen Faculty of Medicine, Department of Nephrology, Hatay, Turkey
}

\begin{abstract}
Objectives: This study aimed to evaluate whether aspirin therapy is effective in protecting against hepatitis $\mathrm{C}$ virus (HCV) infection in maintenance hemodialysis patients, one of the high-risk groups for HCV infection.

Materials and Methods: This retrospective cross-sectional study included 408 patients with end-stage renal failure who underwent maintenance hemodialysis for at least 3 months in four private hemodialysis units in Hatay, Turkey, in January 2017. The patients were classified into two groups according to their aspirin exposure status: non-users $(n=228)$ and regular aspirin users $(n=180)$. The proportion of patients with hemodialysis-related chronic hepatitis $C$ $(\mathrm{CHC})$ was compared between the groups. Irregular aspirin users, patients infected with HBV or diagnosed with $\mathrm{CHC}$ before initiation of hemodialysis therapy were excluded from the study.

Results: The prevalence of hemodialysis-related $\mathrm{CHC}$ was 3.9\% among the 408 patients. Hemodialysis-related $\mathrm{CHC}$ was not seen in any of the 180 regular aspirin users. Regular aspirin users showed a significantly lower prevalence of hemodialysis-related $\mathrm{CHC}$ than non-users $(p<0.001)$. There was a significant $(p<0.001)$, but weak (Cramer's $\mathrm{V}=0.180$ ) correlation between hemodialysis-related $\mathrm{CHC}$ and aspirin exposure status.

Conclusion: These results indicated that regular use of aspirin might be linked to a lower risk of hemodialysis-related $\mathrm{CHC}$. However, further prospective studies are required to confirm this association.

Keywords: Aspirin, chronic hepatitis C, hemodialysis
\end{abstract}

ÖZ

Amaç: $\mathrm{Bu}$ çalışmada hepatit $\mathrm{C}$ virüs (HCV) enfeksiyonu için yüksek risk gruplarından biri olan rutin hemodiyaliz hastalarında aspirin tedavisinin HCV enfeksiyonuna karşı korunmada etkili olup olmadığının değerlendirilmesi amaçlandı.

Gereç ve Yöntemler: Bu retrospektif kesitsel çalışma, Ocak 2017'de Hatay'da bulunan 4 özel hemodiyaliz merkezinde son dönem böbrek yetmezliği nedeniyle en az 3 ay süre ile rutin hemodiyaliz tedavisi almış olan 408 hastayı içermekte idi. Hastalar aspirin kullanım durumlarına göre iki gruba ayrıldı: Illk grup hemodiyaliz başlangııından itibaren hiç aspirin kullanmamış 228 hastadan, ikinci grup ise hemodiyaliz başlangııından itibaren düzenli aspirin kullanmakta olan 180 hastadan oluşmakta idi. Hemodiyaliz ilişkili kronik hepatit $\mathrm{C}(\mathrm{KHC})$ oranları gruplar arasında karşılaştıııldı. HBV ile enfekte, hemodiyaliz tedavisi öncesinde $\mathrm{KHC}$ tanısı almış olan, düzensiz aspirin kullanan hastalar çalıșmaya dahil edilmedi.

Bulgular: Hemodiyaliz ilişkili KHC prevalansı toplam 408 hastada \%3,9 idi. Düzenli aspirin kullanımı olan 180 hemodiyaliz hastasının hiçbirinde hemodiyaliz ilişkili KHC görülmedi. Düzenli aspirin kullanıcılarında hemodiyaliz ilişkili KHC prevalansı hiç aspirin kullanmamış hastalarla karşılaştııılığında anlamlı oranda daha düşük bulundu $(p<0,001)$. Aspirin kullanım durumu ile hemodiyaliz ilişkili $\mathrm{KHC}$ arasında anlamlı $(\mathrm{p}<0,001)$, ancak zayıf (Cramer's $\mathrm{V}=0,180)$ bir korelasyon bulunmakta idi.

Sonuç: Bu sonuçlar düzenli aspirin kullanımının hemodiyaliz ilişkili KHC riskinin azaltılmasında yararlı olabileceğini düşündürmektedir. Bununla birlikte, bu varsayımı doğrulamak için daha ileri prospektif çalışmalara intiyaç vardır.

Anahtar Kelimeler: Aspirin, kronik hepatit C, hemodiyaliz

Bal T, Önlen Y, Şahin Sİ, Turgut FH. Aspirin for Preventing Hemodialysis-associated Chronic Hepatitis C Infections. Viral Hepat J. 2018;24:43-46. 


\section{Introduction}

Hepatitis $\mathrm{C}$ is a global health problem affecting an estimated $2.35 \%$ of the world population, and individuals undergoing maintenance hemodialysis (HD) are known to have a 5-fold greater risk of hepatitis $C$ compared with the general population $(1,2)$. Moreover, it has been reported that the presence of hepatitis $\mathrm{C}$ might be associated with increased mortality and graft rejection in end-stage renal disease patients undergoing HD or kidney transplantation (3).

Despite improvements in the treatment of chronic hepatitis $\mathrm{C}(\mathrm{CHC})$ in $\mathrm{HD}$ patients, this infection remains significant in $\mathrm{HD}$ patients as current treatments cannot prevent re-infections and there is currently no vaccine to prevent hepatitis $C$ (4). Therefore, there is a need for alternative protective measures for the prevention of hepatitis $\mathrm{C}$ in HD patients.

Aspirin, also known as acetylsalicylic acid is a cyclooxygenase-1 (COX-1) and -2 (COX-2) inhibitor which has an antiviral effect on RNA viruses, including hepatitis $C$ virus $(\mathrm{HCV})(5,6)$. In recent years, in vivo and in vitro studies have shown that the use of aspirin increases the efficacy of standard antiviral therapy by suppressing $\mathrm{HCV}$ replication, slowing the progression of liver damage and preventing hepatocellular carcinoma development in $\mathrm{CHC}$ patients $(7,8,9)$. Consistent with these data, Manning et al. (7) showed that successful antiviral therapy resulted in the normalisation of COX-2 over-expression which was induced by HCV infection. Claudin-1 is a tight junction protein which is highly expressed in the liver and known to be an essential factor for HCV entry (10). In a more recent study of the antiviral effect of aspirin, Yin et al. reported that aspirin inhibited the entry of HCV by decreasing the expression of claudin-1 (11).

According to the results of these studies, it was hypothesised that aspirin use may be effective in preventing HCV infections/ re-infections in maintenance HD patients who have an increased risk for $\mathrm{HCV}$ infection. The aim of this study was therefore to investigate whether aspirin use is effective in the prevention of $\mathrm{HCV}$ infection in maintenance HD patients.

\section{Materials and Methods}

We conducted a cross-sectional retrospective study in January 2017 at four private HD units in Hatay, Turkey. A total of 408 patients with end-stage renal failure undergoing maintenance $\mathrm{HD}$ for at least three months were enrolled. Inclusion criteria for this study were (1) maintenance HD for at least three months. Exclusion criteria were (1) diagnosis of $\mathrm{CHC}$ before initiation of HD therapy, (2) being infected with hepatitis B (3) irregular aspirin use ( $<3$ days per week), and (4) age $<18$ years. The participants were interviewed and the following data were obtained using a standardised questionnaire and were checked from medical records: presence of HBV infection, a history of drug abuse, blood transfusion(s) or renal transplantation, aspirin exposure information (dose, the frequency of use) and the date of initiation of HD. In Turkey, HD patients are examined routinely every three months for viral hepatitis and patients with positive anti-HCV are also tested for HCV RNA. Thus, serum anti-HCV and HCV RNA results since the initiation of HD were obtained from medical records retrospectively. The positivity of anti-HCV and HCV RNA for at least six months was defined as $\mathrm{CHC}$. Patients diagnosed with $\mathrm{CHC}$ after initiation of $\mathrm{HD}$ therapy were defined as having HD-related $\mathrm{CHC}$.

The patients were classified in two groups (regular aspirin users and non-users) based on aspirin exposure status since the initiation of HD. These exposure categories were selected according to prior studies showing that the antiviral effect of aspirin for $\mathrm{HCV}$ was time-dependent and was highest at 72 hours post-treatment (12). Regular aspirin use was defined as use of any dose of aspirin at least 3 times per week from the initiation of HD for at least 3 months. Patients, who reported no aspirin use, were defined as non-users. The presence of HD-related $\mathrm{CHC}$, the duration of $\mathrm{HD}$, the rate of patients with a history of blood transfusion or renal transplantation were compared between the two groups.

Low-dose aspirin was defined as a dose of 100-150 mg and high-dose aspirin was defined as a $300 \mathrm{mg}$ dose.

To control microbial contamination of dialysis machines, hotwater (at $80{ }^{\circ} \mathrm{C}$ ) rinsing was applied after each dialysis session and chemical disinfection was performed at the end of the day and at the end of the week. Disposable dialysis kits and needle sets were used and standard precautions, such as hand hygiene, personal protective equipment, and disinfection of equipments and surfaces, were followed. All patients positive for hepatitis B surface antigen and anti-HCV were dialyzed on dedicated dialysis machines in separate rooms. These standard precautions and practices were applied to control infection in each of four HD units.

\section{Statistical Analysis}

SPSS software package was used for statistical analyses (version 23.0, Chicago, IL, USA). Histograms, probability plots and the Kolmogorov-Smirnov/Shapiro-Wilk tests were used for testing of distribution normality. To compare variables between the two groups, the Mann-Whitney $U$ test was used to compare nonnormally distributed variables and chi-square test/Fisher's exact test (where appropriate) for categorical variables. The correlation between aspirin exposure status and the percentage of HD-related $\mathrm{CHC}$ were tested using the chi-square test of Independence. A $\mathrm{p}$-value of less than 0.05 was considered statistically significant.

\section{Results}

The study included 228 non-users and 180 regular aspirin users. Of the 408 patients, 58.3\% were female and $41.7 \%$ were male. The median age of the patients was 60.3 (18-95) years. The median duration of HD was 52 (3-336) months. In the total of 408 patients, the prevalence of HD-related $\mathrm{CHC}$ was 3.9\%. The patients' characteristics are shown in Table 1.

None of the patients had a history of intravenous drug abuse or tattooing.

The most striking result to emerge from the data was that HD-related $\mathrm{CHC}$ infection was not seen in any of the 180 patients who had been receiving aspirin therapy regularly since the initiation of HD.

The chi-square test of independence showed a significant $(p<0.001)$, but weak (Cramer's $V=0.180)$ correlation between HD-related $\mathrm{CHC}$ and aspirin exposure status.

The proportion of patients with HD-related $\mathrm{CHC}$ was significantly lower in the regular aspirin user group than in the non-user group, although patients in the regular aspirin user group were older and 
had a longer duration of HD (in months) than those in the nonuser group. In addition, there was no significant difference in the proportion of patients with HD-related $\mathrm{CHC}$ between the groups when the patients are classified according to the duration of HD (in months) ( $p=0.179$ ) (Table 2).

To analyze any association between aspirin dose and the risk of HD-related $\mathrm{CHC}$, drug exposure data was obtained. Most patients (86.6\%) were using low dose (100-150 mg) aspirin.

\section{Discussion}

In this study, it was investigated whether regular aspirin use was effective in preventing HCV infection in maintenance HD patients. The results indicate that regular use of aspirin may be associated with a decreased risk of HD-related $\mathrm{CHC}$. Previous studies have reported that the expression of HCV proteins increase intracellular reactive oxygen species levels (13). Moreover, a number of authors have reported that antioxidants, including aspirin, modulate the oxidative stress induced by HCV at the same time by decreasing viral replication as well as decreasing viral protein expression. It has been suggested that the antiviral activity of aspirin might be mediated by the modulation of oxidative stress $(14,15)$. Overall, there seems to be some evidence to suggest that aspirin has an antiviral effect against HCV. However, there are only limited data on the prophylactic effect of aspirin against HCV. These results therefore need to be interpreted with caution and large randomised controlled trials could provide more definitive evidence.

Although most studies in the field of the antiviral effect of aspirin have focused on controlling viral replication and protein expression, to the best of our knowledge, a pre-clinical study by Yin et al. is the only one which has directly investigated the potential prophylactic role of aspirin in HCV infection (11). The authors revealed that aspirin inhibited the entry of $\mathrm{HCV}$ by decreasing the expression of claudin-1, which is a tight junction protein that is highly expressed in the liver and an essential factor for $\mathrm{HCV}$ entry $(10,11,14,16)$. This also concurs with previous reports, which showed that aspirin had an anti-HCV effect through down regulation of HCV protein expression $(12,16)$. In the current study, the most important clinically relevant finding was that HD-related $\mathrm{CHC}$ infection was not seen in any of the patients who had been receiving aspirin therapy regularly since the initiation of HD. The present findings seem to be consistent with those of Yin and Zhang (11) and indicate that regularly taking aspirin every other day could protect against $\mathrm{CHC}$ infection in maintenance HD patients. This is also consistent with earlier observations, which showed that the antiviral effect of aspirin was still maximal 3 days after the last administration and the antiviral effect of aspirin was highest at 72 hours post-treatment, because we defined the regular aspirin use as any dose of aspirin $\geq 3$ days per week in the current study (12). Nevertheless, because of the retrospective nature of the study and small number of HD-related $\mathrm{CHC}$ cases this result should be interpreted with caution. Further research on this topic is required to confirm these speculations.

COX-2 has been shown to be over-expressed in patients with $\mathrm{CHC}$ (7). Recent in vitro studies have speculated that COX-2 activity may be involved in aspirin-mediated down regulation of viral replication and protein expression $(12,16)$. Even though aspirin has a very short half-life in plasma, aspirin irreversibly inactivates the COX activity of the platelets and the platelet reactivity has been seen to be normalized 96 hours after the cessation of a single oral dose of $100 \mathrm{mg}$ aspirin $(5,17)$. However, it is unclear whether the antiviral effect of aspirin also continues for 96 hours. Further experimental investigations are needed to determine when this antiviral activity of aspirin disappears after the last dose of aspirin intake in HD patients.

In an investigation of the anti-HCV effect of aspirin, the researchers found that aspirin had a dose-dependent antiviral effect (12). Therefore, to clarify any association between aspirin dose and the risk of HD-related $\mathrm{CHC}$, drug exposure data was obtained.

Table 1. Characteristics of each group and statistical differences between groups

\begin{tabular}{|c|c|c|c|c|}
\hline & & Non-user group $(\mathrm{n}=228)$ & Regular aspirin user group $(n=180)$ & p \\
\hline Gender & Male (\%) & 56.1 & 61.1 & $0.312^{b}$ \\
\hline \multicolumn{2}{|c|}{ Duration of hemodialysis (in months) } & $48(3-336)$ & $72(3-168)$ & $0.020^{a}$ \\
\hline \multicolumn{2}{|c|}{ Presence/proportion of hemodialysis related $\mathrm{CHC}, \mathrm{n}(\%)$} & $16(3)$ & $0(0)$ & $<0.001^{b}$ \\
\hline Blood transfusion(s), n (\%) & No & $157(68.9)$ & $114(63.3)$ & $0.241^{b}$ \\
\hline \multirow[t]{2}{*}{ Renal transplantation, $\mathrm{n}(\%)$} & Yes & $23(10.1)$ & $13(7.2)$ & \multirow[t]{2}{*}{$0.311^{b}$} \\
\hline & No & 205 (89.9) & 167 (92.8) & \\
\hline
\end{tabular}

Table 2. Comparison of the presence of hemodialysis related chronic hepatitis $\mathrm{C}$ between the groups according to the duration of hemodialysis

\begin{tabular}{|c|c|c|c|c|c|}
\hline & \multicolumn{2}{|c|}{ Hemodialysis related $\mathrm{CHC}(+)$} & \multicolumn{2}{|c|}{ Hemodialysis related $\mathrm{CHC}(-)$} & \multirow[t]{2}{*}{$\mathrm{p}$} \\
\hline & Regular aspirin users & Non-users & Regular aspirin users & Non-users & \\
\hline Duration of hemodialysis $\leq 84$ months & 0 & 9 & 159 & 166 & $0.179^{a}$ \\
\hline
\end{tabular}


However, probably because the HD population is at high risk of bleeding events, most patients were using low-dose aspirin (18). Overall, each dose category (low and high-dose) was too small to provide valid results. Therefore, it was not possible to investigate whether there was a relationship between the dose of aspirin and the risk of HD-related $\mathrm{CHC}$. There is a need for further research on this topic to provide a better understanding of the optimal dose of aspirin to reduce the risk of $\mathrm{CHC}$.

\section{Study Limitations}

Finally, a number of important limitations need to be considered. First, the major limitation was the small number of HD-related $\mathrm{CHC}$ cases. Secondly, there was no information about the total number of blood transfusion units since initiation of HD, which may have increased the risk of $\mathrm{HD}$-related $\mathrm{CHC}$ infection. The retrospective nature of the study was another limitation. Despite these limitations, this research is the first clinical trial testing the hypothesis that aspirin has a prophylactic effect against $\mathrm{CHC}$ in a high-risk group, such as the group of HD patients included here. The results of this research provide further support for the hypothesis that the use of aspirin has an antiviral effect against HCV and reduces the risk of $\mathrm{CHC}$.

\section{Conclusion}

Although the current study is based on a small sample of participants, the findings suggested that a regular every other day regimen of low-dose aspirin in maintenance $\mathrm{HD}$ patients might reduce the risk of $\mathrm{CHC}$. Nevertheless, there is a need for further large-scale prospective studies to confirm these findings.

\section{Ethics}

Ethics Committee Approval: This study was approved by the Ethics Committee of Mustafa Kemal University, Faculty of Medicine, Hatay, Turkey (decision date: 09.02.2017, decision number: 12).

Informed Consent: Informed consent was not necessary because of the retrospective design of the study.

Peer-review: Externally peer-reviewed.

\section{Authorship Contributions}

Surgical and Medical Practices: T.B., Design: T.B., Y.Ö., S.I.Ş., F.H.T., Data collection or Processing: T.B., Y.Ö., S.I.S.., F.H.T., Analysis or Interpretation: T.B., Y.Ö., S.I.Ş., F.H.T., Literature Search: T.B., Writing: T.B.

Conflict of Interest: No conflict of interest was declared by the authors.

Financial Disclosure: The authors declared that this study has received no financial support.

\section{References}

1. Lavanchy D. Evolving epidemiology of hepatitis C virus. Clin Microbiol Infect. 2011;17:107-115.

2. Ozer Etik D, Ocal S, Boyacioglu AS. Hepatitis C infection in hemodialysis patients: A review. World J Hepatol. 2015;7:885895.
3. Azmi AN, Tan SS, Mohamed R. Hepatitis C and kidney disease: An overview and approach to management. World $\mathrm{J}$ Hepatol. 2015;7:78-92.

4. Cacoub P, Desbois AC, Isnard-Bagnis C, Rocatello D, Ferri C. Hepatitis $C$ virus infection and chronic kidney disease: Time for reappraisal. J Hepatol. 2016;65(1 Suppl):82-94.

5. Awtry EH, Loscalzo J. Aspirin. Circulation. 2000;101:1206-1218.

6. Glatthaar-Saalmüller B, Mair KH, Saalmüller A. Antiviral activity of aspirin against RNA viruses of the respiratory tract-an in vitro study. Influenza Other Respir Viruses. 2017;11:85-92.

7. Manning DS, Sheehan KM, Byrne MF, Kay EW, Murray FE. Cyclooxygenase-2 expression in chronic hepatitis $\mathrm{C}$ and the effect of interferon alpha treatment. J Gastroenterol Hepatol. 2007;22:1633-1637.

8. Poujol-Robert A, Boëlle PY, Conti F, Durand F, Duvoux C, Wendum D, Paradis V, Mackiewicz V, Chazouillères O, Corpechot C, Poupon R. Aspirin may reduce liver fibrosis progression: Evidence from a multicenter retrospective study of recurrent hepatitis $\mathrm{C}$ after liver transplantation. Clin Res Hepatol Gastroenterol. 2014;38:570-576.

9. Sahasrabuddhe WV, Gunja MZ, Graubard BI, Trabert B, Schwartz LM, Park Y, Hollenbeck AR, Freedman ND, McGlynn KA. Nonsteroidal anti-inflammatory drug use, chronic liver disease, and hepatocellular carcinoma. J Natl Cancer Inst. 2012;104:18081814.

10. Evans MJ, von Hahn T, Tscherne DM, Syder AJ, Panis M, Wölk B, Hatziioannou T, McKeating JA, Bieniasz PD, Rice CM. Claudin-1 is a hepatitis $C$ virus co-receptor required for a late step in entry. Nature. 2007:446:801-805.

11. Yin $P$, Zhang L. Aspirin inhibits hepatitis $C$ virus entry by downregulating claudin-1. J Viral Hepat. 2016;23:62-64.

12. Sánchez-García A, Ríos-lbarra $C P$, Rincón-Sánchez AR, OrtizLópez R, Garza-Juárez A, Morlett-Chávez J, Martínez-Rodríguez $H$, Rivas-Estilla AM. Use of proteomic analysis tools to identify HCV-proteins down-regulated by acetylsalicylic acid. Ann Hepatol. 2013;12:725-732.

13. Gong G, Waris $G$, Tanveer $R$, Siddiqui A. Human hepatitis $C$ virus NS5A protein alters intracellular calcium levels, induces oxidative stress, and activates STAT-3 and NF-kappa B. Proc Natl Acad Sci U S A. 2001;98:9599-9604.

14. Ríos-lbarra CP, Lozano-Sepulveda S, Muñoz-Espinosa L, RincónSánchez AR, Cordova-Fletes C, Rivas-Estilla AM. Downregulation of inducible nitric oxide synthase (iNOS) expression is implicated in the antiviral activity of acetylsalicylic acid in HCV-expressing cells. Arch Virol. 2014;159:3321-3328.

15. Lozano-Sepulveda SA, Bryan-Marrugo OL, Cordova-Fletes C, Gutierrez-Ruiz MC, Rivas-Estilla AM. Oxidative stress modulation in hepatitis C virus infected cells. World J Hepatol. 2015;7:28802889.

16. Trujillo-Murillo K, Rincón-Sánchez AR, Martínez-Rodríguez H, Bosques-Padilla F, Ramos-Jiménez J, Barrera-Saldaña HA, Rojkind M, Rivas-Estilla AM. Acetylsalicylic acid inhibits hepatitis $C$ virus RNA and protein expression through cyclooxygenase 2 signaling pathways. Hepatology. 2008;47:1462-1472.

17. Lee J, Kim JK, Kim JH, Dunuu T, Park SH, Park SJ, Kang JY, Choi RK, Hyon MS. Recovery time of platelet function after aspirin withdrawal. Curr Ther Res Clin Exp. 2014;76:26-31.

18. Steinhubl SR, Bhatt DL, Brennan DM, Montalescot G, Hankey GJ, Eikelboom JW, Berger PB, Topol EJ; CHARISMA Investigators. Aspirin to prevent cardiovascular disease: the association of aspirin dose and clopidogrel with thrombosis and bleeding. Ann Intern Med. 2009;150:379-386. 